\title{
INTEGRASI METODE ANALYTICAL NETWORK PROCESS (ANP) DAN TECHNIQUE FOR OTHERS PREFERENCE BY SIMILARITY TO IDEAL SOLUTION (TOPSIS) DALAM MENENTUKAN PRIORITAS SUPPLIER BAHAN BAKU (Studi Kasus PT Nyonya Meneer Semarang)
}

\author{
Dyah Ika Rinawati *), Mochamad Irfan Try Handoko *) \\ Program Studi Teknik Industri Universitas Diponegoro \\ Jl. Prof. H. Soedarto, SH, Tembalang Semarang 50239
}

\begin{abstract}
Abstrak
Salah satu faktor yang mempengaruhi performansi perusahaan adalah keberadaan supplier yang berperan sebagai penyedia bahan baku. Pemilihan supplier merupakan sebuah pengambilan keputusan multi kriteria, karena banyak faktor yang bersifat kualitatif maupun kuantitatif dapat mempengaruhi performansi supplier. Sehingga tujuan dalam penelitian ini adalah untuk menentukan supplier yang diprioritaskan PT Nyonya Meneer Semarang dalam memenuhi kebutuhan bahan baku jahe, temulawak, kencur, sambiloto dan pegagan. Kemudian dilakukan pengelompokkan 5 item bahan baku dengan menggunakan model Kraljic Portfolio Matrix. Berdasarkan perhitungan diperoleh hasil yakni bahan baku jahe, kencur dan temulawak termasuk kedalam kategori kuadran critical. Metode Analytical Network Process (ANP) dapat dijadikan alternatif untuk suatu permasalahan yang memiliki banyak subkriteria yang saling berkaitan atau berpengaruh dalam pengambilan keputusan dan untuk perankingan supplier dengan metode Technique For Orders Preference by Similarity to Ideal Solution (TOPSIS). Terdapat 13 subkriteria yang digunakan dalam penentuan prioritas supplier. Berdasarkan pembobotan subkriteria dengan menggunakan ANP, subkriteria yang paling besar pengaruhnya dalam penentuan prioritas supplier adalah harga penawaran sebesar 0,2736. Selanjutnya untuk penentuan prioritas supplier dilakukan dengan menggunakan metode TOPSIS dimana bobot subkriteria diperoleh dari pengolahan metode ANP.
\end{abstract}

Kata Kunci : penentuan prioritas supplier, kraljic portfolio matrix, ANP, TOPSIS

\begin{abstract}
One of the factors that influence the company performance is the presence of suppliers which supplies raw materials. Selection of suppliers is a Multi-Criteria Decison Problem, because many factors are qualitative and quantitative data can affect the performance of suppliers. So the purpose of this research is to determine the priority supplier companies to meet the raw material needs of jahe, temulawak, kencur, sambiloto and pegagan. Then do the classify 5 principal materials using Kraljic Portfolio Matrix. Based on the results of the calculations, the raw material of jahe, temulawak and kencur included into the category of critical quadrant. Analytical Network Process (ANP) can be used as an alternative to solve a problem that has many interrelated sub-criteria or influence in decision-making and Technique For Orders Preference by Similarity to Ideal Solution (TOPSIS) method for rangking suppliers. There are 13 sub-criteria used in the prioritization of suppliers. Based on the weighted sub-criteria by using the ANP, subcriteria that most influence in determining the priority of suppliers are offering price of 0.2736. Furthermore, to the supplier prioritization is done by using the TOPSIS method where the weight of subcriteria obtained from ANP method.
\end{abstract}

Keyword : priority of suppliers determination, kraljic portfolio matrix, ANP, TOPSIS

\footnotetext{
${ }^{*}$ ) Penulis Korespondensi.

email: dyah.ika@gmail.com, irfant.handoko@gmail.com
} 


\section{Pendahuluan}

Dalam perkembangan dewasa ini, salah satu faktor yang mempengaruhi performansi perusahaan adalah keberadaan supplier. Pemilihan supplier merupakan kegiatan strategis, terutama apabila supplier tersebut akan memasok item yang kritis dan/atau akan digunakan dalam kegiatan jangka panjang sebagai supplier penting. Kriteria pemilihan merupakan salah satu hal penting dalam pemilihan supplier. Kriteria yang digunakan tentunya harus mencerminkan strategi supply chain maupun karakteristik dari item yang akan dipasok. Banyak permintaan menggunakan kriteria dasar seperti kualitas barang yang ditawarkan, harga, dan ketepatan waktu pengiriman. Bagaimanapun juga, pemilihan supplier membutuhkan berbagai kriteria lain yang dianggap penting oleh perusahaan. Setelah kriteria ditetapkan dan beberapa kandidat supplier diperoleh, maka perusahaan harus melakukan pemilihan. Perusahaan akan memilih satu atau beberapa alternatif yang ada melalui perangkingan. Perengkingan dilakukan untuk memnentukan mana supplier yang akan dipilih atau mana yang akan dijadikan sebagai supplier utama dan mana yang akan dijadikan supplier cadangan. Evaluasi supplier dilakukan apabila bahan baku yang sama diperoleh lebih dari satu supplier (Pujawan 2005).

PT Nyonya Meneer Semarang merupakan perusahaan yang memproduksi berbagai jenis jamu dan kosmetik berkualitas dengan menggunakan bahan baku dari alam. Dalam menjalankan kegiatan operasionalnya, PT Nyonya Meneer Semarang memperoleh pasokan bahan baku dari para supplier. PT Nyonya Meneer Semarang membutuhkan 108 macam bahan baku untuk memproduksi sebanyak 254 merek dengan macam-macam bentuk yakni pil, kapsul, serbuk, dan cairan dengan kegunaan yang berbeda yakni untuk perawatan tubuh, kecantikan, dan penyembuhan. Sehingga para supplier dari berbagai macam jenis bahan baku bersaing demi mendapatkan kontrak sebagai supplier dari PT Nyonya Meneer Semarang. Diantara 108 macam bahan baku, PT Nyonya Meneer Semarang memiliki 5 macam bahan baku utama, antara lain jahe, temulawak, kencur, pegagan dan sambiloto.

Dalam menjalankan proses pengadaan bahan baku, kerjasama yang terjalin antara PT Nyonya Meneer Semarang dengan para supplier bahan baku kurang memuaskan, dimana seringkali terjadi keterlambatan kedatangan bahan baku dari para supplier. Tetapi fakta yang terjadi bahwa PT Nyonya Meneer Semarang telah membuat penjadwalan untuk setiap kedatangan bahan baku dari supplier pada tiap periode pengiriman, dimana jadwal tersebut dibuat berdasarkan penjadwalan produksi. Permasalahan selanjutnya adalah terdapat peningkatan persentase kecacatan yang signifikan selama tahun 2013-2014. Dimana supplier yang menjadi prioritas utama justru menunjukkan persentase kecacatan tertinggi untuk tiap periode pengiriman. Seringkali kualitas dari bahan baku dengan kadar air lebih dari $10 \%$ bahkan kurang dari $8 \%$ dinilai telah rusak dan tidak dapat digunakan oleh perusahaan untuk memproduksi berbagai jenis jamu dan kosmetik sehingga mengakibatkan kerugian bagi PT Nyonya Meneer Semarang. Permasalahan selanjutnya adalah PT Nyonya Meneer Semarang dalam memilih dan menentukan supplier mana yang harus diprioritaskan terlebih dahulu hanya mempertimbangkan kriteria harga dari bahan baku yang ditawarkan oleh tiap supplier.

Berdasarkan permasalahan diatas, penelitian ini berfokus pada strategi purchasing dan pemilihan dan penentuan supplier yang diprioritaskan untuk PT Nyonya Meneer Semarang. Pemilihan supplier merupakan masalah pengambilan keputusan yang cukup penting, karena pemilihan supplier yang berkualitas akan menghasilkan produk berkualitas pula, sehingga dapat melakukan efisiensi biaya pembelian, meningkatkan kepuasan pelanggan dan meningkatkan kemampuan kompetitif perusahaan (Liao dan Kao, 2010). Berdasarkan permasalahan diatas, penelitian ini bertujuan untuk memilih dan menentukan urutan prioritas supplier pada PT Nyonya Meneer Semarang. Pemilihan supplier merupakan masalah pengambilan keputusan yang cukup penting, karena pemilihan supplier yang berkualitas akan menghasilkan produk berkualitas pula. Oleh karena itu pada penelitian ini menggunakan model Kraljic Portfolio Matrix (KPM) melakukan klasifikasi kekritisan item terhadap bahan baku jahe, temulawak, kencur, sambiloto dan pegagan dan menggunakan metode Analytic Network Process (ANP) yang dikombinasikan dengan Technique for Order Preference by Similarity to Ideal Solution (TOPSIS) untuk memberikan rekomendasi urutan prioritas supplier bahan baku pada PT Nyonya Meneer Semarang.

\section{Metodologi Penelitian}

Metodologi penelitian ini digunakan sebagai acuan dalam melakukan penelitian sehingga dapat berjalan dengan sistematis. Maka siklus pemecahan masalah dapat dilaksanakan secara terstruktur.

\section{Identifikasi Kriteria}

Pada tahap ini dilakukan penentuan kriteria untuk strategi purchasing pada PT Nyonya Meneer Semarang yang disesuaikan dengan keadaan empirik di lapangan. Menurut Teimoury dan Mirahmadi (2012) terdapat hubungan positif antara profit impact dengan risk factor, dimana kriteria-kriteria yang digunakan dalam penelitian ini antara lain menurut Seifbarghy (2009) dalam Fany Juanita (2013), penelitian Prostean, dkk (2014) dan dalam penelitian Knight, dkk (2014) dapat dilihat pada Tabel 1. Sedangkan kriteria- 
kriteria pemilihan supplier yang digunakan dalam penelitian ini antara lain menurut Singh (2011), Lin dan Chen (2011) dalam Kurniawati (2013) dan Dickson (1996) dalam Wardah (2013) serta berdasarkan brainstorming dengan pihak pembelian bahan baku PT Nyonya Meneer Semarang dapat dilihat pada Tabel 2.

Tabel 1. Kriteria Supply Risk Dan Profit Impact

\begin{tabular}{cl}
\hline Dimensi & \multicolumn{1}{c}{ Kriteria } \\
\hline & Resiko penyimpanan \\
& Ketersediaan item pengganti \\
& Jumlah supplier yang digunakan \\
Supply Risk & Jumlah supplier yang potensial \\
& Kompetisi \\
& Kelangkaan item \\
& Lead time \\
Profit & Harga item \\
Impact & Volume jumlah pembelian \\
& Kualitas item \\
\hline
\end{tabular}

Tabel 2. Kriteria Penentuan Prioritas Supplier

\begin{tabular}{|c|c|c|}
\hline Kriteria & Kode & Subkriteria \\
\hline \multirow{3}{*}{ Quality } & A1 & $\begin{array}{l}\text { Kemampuan memanajemen } \\
\text { tingkat kecacatan }\end{array}$ \\
\hline & $\mathrm{A} 2$ & Tingkat pengembalian \\
\hline & A3 & $\begin{array}{l}\text { Kadar air/tingkat kekeringan bahan } \\
\text { baku }\end{array}$ \\
\hline \multirow{3}{*}{ Cost } & B1 & Biaya transportasi \\
\hline & B2 & Harga penawaran \\
\hline & B3 & Potongan harga \\
\hline \multirow{2}{*}{ Delivery } & $\mathrm{C} 1$ & Ketepatan kuantitas pesanan \\
\hline & $\mathrm{C} 2$ & Ketepatan waktu pengiriman \\
\hline \multirow{3}{*}{ Service } & D1 & Waranties and claim policies \\
\hline & D2 & Communication System \\
\hline & D3 & Responsiveness \\
\hline \multirow{2}{*}{ Flexibility } & E1 & $\begin{array}{l}\text { Fleksibel terhadap perubahan } \\
\text { jumlah pesanan }\end{array}$ \\
\hline & $\mathrm{E} 2$ & $\begin{array}{l}\text { Fleksibel terhadap perubahan } \\
\text { waktu pengiriman }\end{array}$ \\
\hline
\end{tabular}

\section{Kuesioner}

Pada penelitian ini menggunakan 5 tahapan kuesioner. Kuesioner pertama adalah kuasioner yang digunakan untuk melakukan penilaian terhadap tingkat kepentingan tiap kriteria (supply risk dan profit impact) dan kuesioner kedua digunakan untuk mengidentifikasi item pembelian (bahan baku) yang dipasok PT Nyonya Meneer Semarang dari supplier terhadap tiap kriteria, kuesioner ketiga adalah untuk mengetahui hubungan antar subkriteria sebagai acuan dasar untuk membuat model ANP. Kuesioner keempat adalah kuesioner perbandingan berpasangan yang digunakan untuk mendapatkan bobot kepentingan tiap subkriteria. Dan kuesioner kelima digunakan untuk menentukan nilai judgement setiap subkriteria terhadap setiap alternatif yakni supplier dari tiap bahan baku.

\section{Responden}

Responden yang terlibat pada penelitian ini adalah kepala bagian pembelian dan dua staff ahli bagian pembelian. Responden ini dipilih karena dianggap menguasai dan memahami kegiatan pengadaan bahan baku di PT Nyonya Meneer Semarang dari para supplier.

$\mathrm{Q}=\mathrm{N} / 2$

$\mathrm{N}=$ Jumlah responden, Jika $\mathrm{Vij} \geq \mathrm{Q}$ maka ada hubungan saling ketergantungan antar kriteria, Vij $<Q$ maka tidak terdapat hubungan saling ketergantungan antar kriteria. $\mathrm{Vij}=$ Jumlah responden yang memilih adanya hubungan saling ketergantungan antar subkriteria pada sel baris i dengan kolom j. (Wibowo, 2010 dalam Kurniawati, 2013)

\section{Pengolahan Data}

Memposisikan Item Menggunakan Kraljic Portfolio Matrix

Kraljic memperkenalkan sebuah portfolio yang menjelaskan purchasing dan supply management. Kraljic (1983) dalam Gelderman, dkk (2006) menyusun sebuah portfolio matrix yang mengklasifikasikan karakteristik produk berdasarkan 2 dimensi yaitu profit impact dan supply risk (low dan high). Sebuah matriks mengidentifikasi empat tahap: (1) manajemen pembelian; (2) manajemen bahan; (3) manajemen sumber; dan (4) manajemen persediaan. Pada tahap pertama, perusahaan mengklasifikasikan semua produk yang dibeli dari segi profit impact dan supply risk. Selanjutnya, tingginya daya tawar pemasok terhadap kekuatan perusahaan. Kemudian, perusahaan menempatkan produk yang diidentifikasi dalam tahap pertama sebagai strategis (profit impact tinggi dan supply risk tinggi) dalam matriks portfolio. Akhirnya, mengembangkan strategi pembelian dan rencana aksi untuk produk-produk strategis, tergantung pada kekuatan sendiri dan kekuatan pasar pasokan. Berikut adalah langkah-langkah dari Kraljic Portofolio Matrix (Sidhartha,dkk 2012) :

1. Pada tahap awal, hasil pengisian kuesioner tahap pertama dan kedua oleh para responden dikonversi menjadi suatu bilangan Triangular Fuzzy Numbers (TFN). Kemudian bedakan hasil konversi berdasarkan dimensi profit impact dan supply risk.

Tabel 3. Skala Triangular Fuzzy Number (TFN)

\begin{tabular}{cc}
\hline Linguistic Scale Point & Triangular Fuzzy Number \\
\hline None & $\{1,1,2\}$ \\
Extremely low & $\{1,2,3\}$ \\
Very low & $\{2,3,4\}$ \\
Low & $\{3,4,5\}$ \\
Medium low & $\{4,5,6\}$ \\
Medium & $\{5,6,7\}$ \\
Medium high & $\{6,7,8\}$ \\
High & $\{7,8,9\}$ \\
Very high & $\{8,9,10\}$ \\
\hline
\end{tabular}




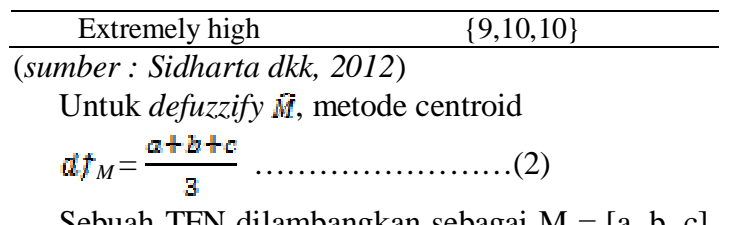

Sebuah TFN dilambangkan sebagai $\mathrm{M}=[\mathrm{a}, \mathrm{b}, \mathrm{c}]$, Dengan $0 \leq \mathrm{a} \leq \mathrm{b} \leq \mathrm{c}$. Dimana menggabungkan suatu penilaian fuzzy multi-atribut utilitas dengan teknik penyelesaian Multidimensional Scale (MDS), dimana atribut (kriteria) terkait diposisikan menjadi dua dimensi supply risk dan profit impact.

2. Menghitung rata-rata nilai kepentingan tiap kriteria, Yakni dengan menggunakan rumus : $\overline{\bar{\theta}}_{m}=\frac{\sum_{\varepsilon=1}^{M} \bar{\theta}_{m m}}{E}, \forall_{m}=1,2, \ldots \mathrm{M} \ldots(3)$

Hasil rekapitulasi dapat dilihat pada Tabel 8, dimana e adalah indeks untuk responden, $\mathrm{e}=1$, $2, \ldots \mathrm{E}(\mathrm{E}=$ jumlah responden $)$ dan $\mathrm{m}$ adalah indeks untuk atribut (kriteria), di mana $\mathrm{m}=1$, $2, \ldots \mathrm{M}(\mathrm{M}=$ dibedakan berdasarkan dimensi profit impact dan supply risk). Dibawah ini merupakan vektor yang menunjukkan nilai ratarata kepentingan yakni $\mathrm{AG}_{\mathrm{SR}}$ untuk kriteria supply risk, dan $\mathrm{AG}_{\mathrm{PI}}$ untuk kriteria profit impact.

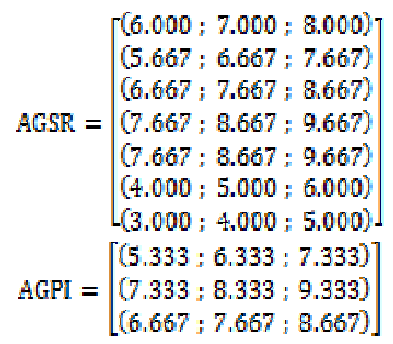

3. Menghitung normalisasi bobot atribut dilakukan untuk mendapatkan normalisasi bobot kriteria supply risk dan profit impact berdasarkan skor kepentingan. Dengan melakukan langkah a,b dan c, antara lain :

a) Membentuk suatu matriks perbandingan berpasangan berdasarkan nilai rata-rata kepentingan tiap atribut (kriteria) untuk penilaian matriks fuzzy AG'. AG' adalah matriks $(M x M)$. Dimana $\mathrm{M}=$ banyaknya jumlah kriteria (kriteria supply risk dan profit impact). Berikut adalah rumus untuk mendapatkan vektor bobot fuzzy.

$$
\begin{aligned}
& \hat{\lambda}_{11}=\frac{\overline{\bar{\theta}}_{1}}{\bar{\nu}_{1}} ; \hat{\lambda}_{12}=\frac{\bar{g}_{1}}{\bar{\nu}_{2}} ; \ldots \hat{\lambda}_{(M-2 M}=\frac{\overline{\bar{\theta}}_{M-1}}{\overline{\bar{\theta}}_{M}} ; \hat{\lambda}_{M M} \\
& =\frac{\overline{\mathrm{z}} M}{\overline{\bar{p}} \mathrm{AN}} \\
& A G^{\prime}=\left[\begin{array}{cccc}
(1,1,1) & \lambda_{12} & \cdots & \lambda_{1 V} \\
\lambda_{21} & (1,1,1) & \cdots & \lambda_{2 M} \\
\vdots & \vdots & \cdots & \vdots \\
\lambda_{M 1} & \lambda_{M 2} & \cdots & (1,1) 1
\end{array}\right]
\end{aligned}
$$

b) Dengan menggunakan pendekatan Deng (1999) untuk menentukan bobot atribut fuzzy $\left(\beta_{m}\right)$ berdasarkan matriks $A G^{\prime}$ dengan menggunakan rumus sebagai berikut :

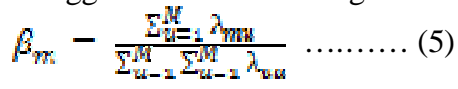

c) Defuzzify bobot atribut fuzzy dengan menggunakan persamaan (1) dimana $\mathrm{m}=1,2$, ... M, ( $\mathrm{M}=$ dibedakan berdasarkan dimensi profit impact dan supply risk). Kemudian menghitung $N W m$, yakni normalisasi bobot dari atribut $m$ th, dengan membagi bobot prioritas atribut $m$ th terhadap total bobot. Hasil rekapitulasi normalisasi bobot terdapat pada Tabel 9.

$$
N W_{m}=\frac{\beta_{m}}{\sum m=a \beta_{m}}
$$

4. Pada tahap ini dilakukan perhitungan untuk memperoleh performance score berdasarkan kuesioner tahap kedua, kemudian menghitung average performance score. Performance dari sebuah item pembelian (bahan baku) dapat dianggap sebagai nilai utilitas dan dapat dievaluasi dengan mengalikan bobot yang telah dinormalisasi $\left(N W_{m}\right)$ untuk setiap atribut dengan merata-ratakan average achievement score $\left((1 / \mathrm{E}) \sum_{\mathbb{E}-1}^{E} \mathcal{X}_{j \mathrm{me}}\right)$ dan $\hat{S}_{j}=$ jumlah nilai dari tiap kriteria untuk setiap item pembelian (bahan baku), $(\mathrm{E}=$ jumlah responden $)$, dinyatakan dengan persamaan dibawah ini:

$\hat{\xi}_{j}=\Sigma_{m=1}^{M}\left[N w_{m} \frac{1}{3} \Sigma_{s=1}^{E} \hat{X}_{m s}\right] \forall_{j}=1,2 . ., \mathrm{J} \ldots(7)$ Hasil rekapitulasi Performance Score dan Average Performance Score terdapat pada Tabel 10.

5. Memposisikan item dengan menggunakan Multidimensional Scale (MDS). MDS digunakan untuk menemukan dimensi dan pola titik yang stukturnya memiliki jarak paling tepat dengan input data. Untuk kasus ini dua sumbu MDS adalah supply risk dan profit impact. Untuk ndimensi, rumus jarak Euclidean dapat dinyatakan sebagai berikut:

$$
d_{j k}=\sqrt{\sum_{t-1}^{n}\left(s_{i j}-s_{i k}\right)^{2}}
$$

Dimana $s_{i j}$ dan $s_{i k}$ menunjukkan utility score dari setiap item pembelian (bahan baku) $j$ dan $k$ masing-masing, $i=1,2, \ldots, \mathrm{n}$. Dalam hal ini $\mathrm{n}=2$ (supply risk dan profit impact). Kemudian hasil jarak Euclidean tersebut akan dijadikan sebagai inputan data pada pengolahan Multidimensional Scale (MDS) (menggunakan software SPSS 16). Berikut adalah output software SPSS 16 menggunakan metode Multidimensional Scale (MDS). Berdasarkan hasil perhitungan pada tabel 4, diperoleh output berupa posisi dari item bahan baku menggunakan Kraljic Portfolio Matrix (KPM). Output berupa titik titik kordinat tiap item bahan baku untuk kedua dimensi supply risk 
(Dimension 1) dan profit impact (Dimension 2). Dimana posisi bahan baku yang berada pada kuadran critical diantaranya jahe, temulawak dan kencur, sedangkan bahan baku sambiloto dan pegagan berada pada kuadran routine.

\section{Perhitungan Bobot Kepentingan Tiap Subkriteria dengan Metode ANP}

1. Penentuan Hubungan Antar Subkriteria

Pada tahap ini dilakukan penentuan hubungan ketergantungan antar subkriteria dalam satu kelompok (inner dependency) dan antar kelompok (outer dependency). Penentuan hubungan ketegantungan tersebut diperoleh dengan menggunakan pengisian kuesioner yang didasarkan pada penelitian (Wibowo, 2010 dalam Kurniawati, 2013). Jumlah responden yang terlibat dalam pengisian kuesioner penentuan hubungan antar subkriteria adalah 3 orang, sehingga apabila didalam satu sel jumlah responden yang memilih (Vij) lebih atau sama dengan Q. Dimana $Q$ adalah N/2=3/2=1,5 (persamaan 1). Maka jika dalam suatu sel jumlah responden yang memilih sebanyak 2 atau 3 responden, subkriteria tersebut dianggap adanya hubungan ketergantungan. Sebagai contoh, pada tabel 4, sebanyak 2 dari 3 responden menyatakan bahwa A3 (kadar air/tingkat kekeringan bahan baku) dipengaruhi oleh subkriteria A1 (kemampuan memanajemen tingkat kecacatan). Berdasarkan perhitungan menggunakan rumus $\mathrm{Q}$, dapat disimpulkan bahwa adanya hubungan keterkaitan antara subkriteria kemampuan memanajemen tingkat kecacatan yang dipengaruhi oleh kadar air/tingkat kekeringan bahan baku.

Tabel 4. Perhitungan Jarak Euclidean

\begin{tabular}{cccccc}
\hline & Jahe & Temulawak & Kencur & Sambiloto & Pegagan \\
\hline Jahe & 0 & 0.1700 & 0.2846 & 0.7393 & 0.6699 \\
Temulawak & 0.1700 & 0 & 0.1348 & 0.5528 & 0.4560 \\
Kencur & 0.2846 & 0.1348 & 0 & 0.4195 & 0.3217 \\
Sambiloto & 0.7393 & 0.5528 & 0.4195 & 0 & 0.1014 \\
Pegagan & 0.6699 & 0.4560 & 0.3217 & 0.1014 & 0 \\
\hline
\end{tabular}

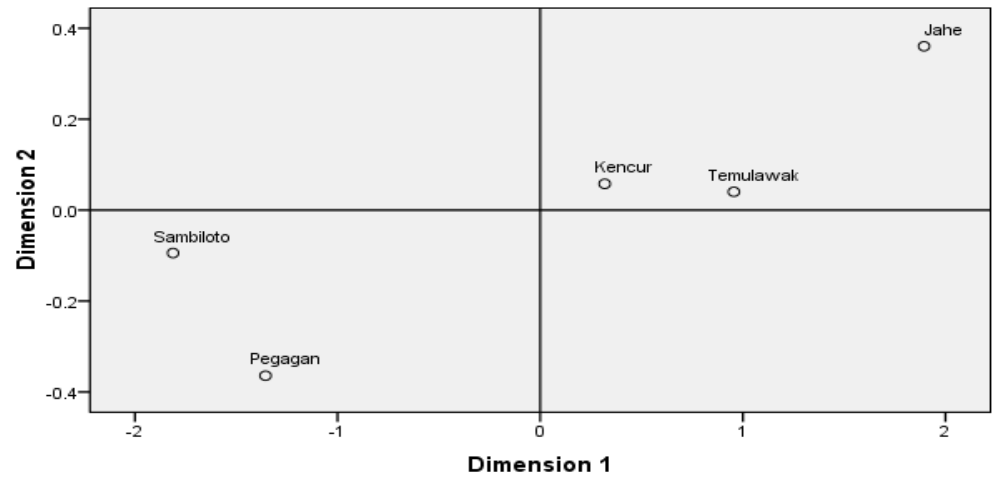

Gambar 1. Mapping Item Output SPSS 16

Tabel 5. Rekapitulasi Kuesioner Hubungan Antar Subkriteria

\begin{tabular}{|c|c|c|c|c|c|c|c|c|c|c|c|c|c|c|}
\hline & & & & & & arial & Yan & Dip & gar & & & & & \\
\hline & & A1 & A2 & $\mathrm{A} 3$ & B1 & $\mathrm{B} 2$ & B3 & $\mathrm{C} 1$ & $\mathrm{C} 2$ & D1 & D2 & D3 & E1 & E2 \\
\hline & A1 & & 3 & 2 & 3 & 2 & & 1 & & 2 & 1 & & & \\
\hline$\overline{\text { E् }}$ & A2 & 3 & & 2 & 2 & & & 1 & & 2 & & 1 & & \\
\hline 0 & A3 & 2 & & & 3 & 2 & & 1 & & & & & 1 & \\
\hline ๕ & B1 & 2 & 2 & 3 & & 3 & 2 & 3 & 3 & 1 & & 2 & 2 & 2 \\
\hline$\stackrel{\Xi}{2}$ & B2 & 1 & 2 & 2 & 1 & & 1 & 2 & 2 & & & & 1 & 1 \\
\hline$\sum_{00}$ & B3 & & & & 2 & & & & 2 & & & & 2 & 3 \\
\hline స్ & $\mathrm{C} 1$ & 1 & & 1 & 2 & 1 & & & & 1 & 1 & & & \\
\hline 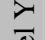 & $\mathrm{C} 2$ & & & & 2 & & 2 & & & & 1 & 1 & & 1 \\
\hline ह & D1 & & 2 & 2 & 1 & & & 3 & 2 & & & 1 & 1 & 1 \\
\hline $\bar{\Xi}$ & D2 & 1 & & & & & & 2 & 2 & 1 & & & 1 & 1 \\
\hline & D3 & & 1 & & 2 & & 2 & 1 & 1 & & 3 & & 2 & 2 \\
\hline & E1 & & & & 2 & & & 1 & & & 1 & 1 & & \\
\hline
\end{tabular}


\begin{tabular}{c|c} 
E2 & 2 \\
\hline hasil identifikasi ada atau tidak
\end{tabular}

2. Berdasarkan hasil identifikasi ada atau tidak
adanya hubungan keterkaitan inner dependence dan outer dependence antar subkriteria, dapat dibuat kerangka ANP berdasarkan hubungan keterkaitan antar subkriteria terkait menggunakan software super decision dan menentukan hubungan antar subkriteria selanjutnya model ANP ini akan digunakan untuk melakukan perbandingan berpasangan berdasarkan kuesioner tahap tiga yang telah disebarkan kepada responden yang telah ditentukan. Kuesioner ini dibuat untuk mengetahui hubungan ketergantungan antar subkriteria dalam satu kriteria yang sama (inner dependence) atau dalam kriteria yang berbeda (outer dependence). Dengan memasukkan penilaian ahli, melalui perbandingan berpasangan dengan tingkat kepentingan 1-9 seperti pada Tabel 6. Berikut adalah kerangka ANP menggunakan software super decision.

3. Berdasarkan output software super decision, menunjukkan bahwa nilai bobot kepentingan untuk setiap subkriteria terdapat pada kolom normalized by all element. Dimana nilai normalized by all element adalah nilai bobot yang digunakan sebagai data input pada perhitungan metode TOPSIS. Dengan metode TOPSIS dapat menentukan prioritas supplier untuk tiap bahan baku pada PT Nyonya Meneer Semarang. Subkriteria yang memiliki bobot kepentingan paling tinggi adalah harga penawaran yaitu sebesar 0,2736. Berikut ini adalah rekapitulasi bobot kepentingan tiap subkriteria.

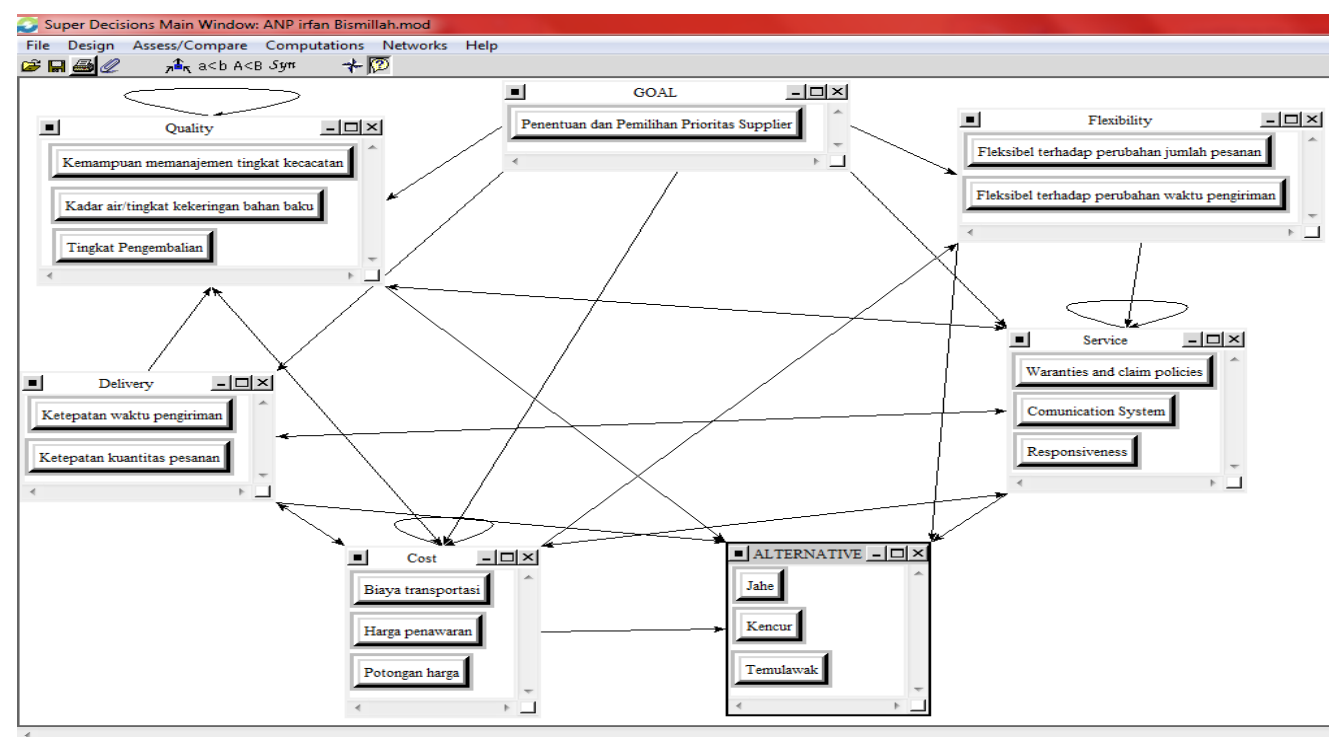

Gambar 2. Kerangka ANP

Tabel 6. Skala Perbandingan

\begin{tabular}{|c|c|c|}
\hline $\begin{array}{c}\text { Tingkat } \\
\text { kepentingan }\end{array}$ & Definisi & Keterangan \\
\hline 1 & Sama pentingnya & Kedua elemen mempunyai pengaruh yang sama. \\
\hline 3 & Sedikit lebih penting & $\begin{array}{l}\text { Penilaian lebih sedikit memihak pada salah satu } \\
\text { elemen dibandingkan pasangannya. }\end{array}$ \\
\hline 5 & Lebih penting & $\begin{array}{l}\text { Penilaian sangat memihak pada salah satu } \\
\text { elemen dibandingkan pasangannya }\end{array}$ \\
\hline 7 & Sangat penting & $\begin{array}{l}\text { Salah satu elemen sangat berpengaruh dan } \\
\text { dominasinya tampak secara nyata }\end{array}$ \\
\hline 9 & Mutlak lebih penting & $\begin{array}{l}\text { Bukti bahwa salah satu elemen lebih penting } \\
\text { daripada pasangannya pada tingkat keyakinan } \\
\text { tertinggi. }\end{array}$ \\
\hline $2,4,6,8$ & $\begin{array}{l}\text { Nilai tengah diantara } \\
\text { judgement diatas }\end{array}$ & $\begin{array}{l}\text { Nilai ini diberikan jika terdapat keraguan } \\
\text { diantara } 2 \text { penilaian yang berdekatan. }\end{array}$ \\
\hline Kebalikan & $\begin{array}{l}\text { aij = 1/aij (jika untuk } \\
\text { dengan aktivitas j mak }\end{array}$ & $\begin{array}{l}\text { ktivitas i mendapat satu angka bila dibandingkan } \\
\text { a j mempunyai nilai kebalikannya dibanding i). }\end{array}$ \\
\hline
\end{tabular}


Tabel 7. Rekapitulasi Bobot Kepentingan Subkriteria

\begin{tabular}{|c|c|c|c|}
\hline Kriteria & Subkriteria & Limiting & $\begin{array}{l}\text { Normalized by } \\
\text { all element }\end{array}$ \\
\hline \multirow{3}{*}{ Cost } & Biaya transportasi & 0,0528 & 0,0976 \\
\hline & Harga penawaran & 0,1481 & 0,2736 \\
\hline & Potongan harga & 0,0379 & 0,0700 \\
\hline \multirow{2}{*}{ Delivery } & Ketepatan kuantitas pesanan & 0,0307 & 0,0567 \\
\hline & Ketepatan waktu pengiriman & 0,0294 & 0,0543 \\
\hline \multirow{2}{*}{ Flexibility } & Fleksibel terhadap perubahan jumlah pesanan & 0,0156 & 0,0289 \\
\hline & Fleksibel terhadap perubahan waktu pengiriman & 0,0179 & 0,0331 \\
\hline \multirow{4}{*}{ Quality } & Kadar air/tingkat kekeringan bahan baku & 0,0457 & 0,0845 \\
\hline & Kemampuan memanajemen tingkat kecacatan & 0,0544 & 0,1007 \\
\hline & Tingkat Pengembalian & 0,0192 & 0,0355 \\
\hline & Comunication System & 0,0181 & 0,0336 \\
\hline \multirow[t]{2}{*}{ Service } & Responsiveness & 0,0636 & 0,1176 \\
\hline & Waranties and claim policies & 0,0076 & 0,0140 \\
\hline Total & & 0,5412 & 1,0000 \\
\hline
\end{tabular}

\section{Penentuan Prioritas Supplier Menggunakan Metode TOPSIS}

Setelah didapatkan bobot kepentingan untuk masing-masing subkriteria maka tahapan selanjutnya adalah meranking prioritas untuk alternatif supplier yang dianggap paling sesuai untuk PT Nyonya Meneer Semarang. Metode ini memiliki prinsip dasar yaitu bahwa alternatif terbaik adalah salah satu yang paling dekat dengan solusi ideal positif dan terjauh dari solusi ideal negatif. Maka asumsi dasar dari TOPSIS adalah ketika solusi ideal positif tidak dapat dicapai, pembuat keputusan akan mencari solusi yang sedekat mungkin dengan solusi ideal positif. TOPSIS memberikan solusi ideal positif yang relatif dan bukan solusi ideal positif yang absolut. Dalam metode TOPSIS klasik, nilai bobot dari setiap kriteria telah diketahui dengan jelas. Setiap bobot kriteria ditentukan berdasarkan tingkat kepentingannya menurut pengambil keputusan. (Wang, Y. M, 2006 dalam Wulandari, 2014). Metode TOPSIS mempertimbangkan keduanya, jarak terhadap solusi ideal positif dan solusi ideal negatif dengan mengambil kedekatan relatif terhadap solusi ideal positif. Adapun tahapan dari metode TOPSIS adalah sebagai berikut ( Shahroudi, dkk 2012):

Tahap awal yang dilakukan dalam metode TOPSIS adalah pengisian kuesioner tahap lima. Kuesioner ini digunakan untuk menentukan nilai judgement setiap subkriteria terhadap setiap alternatif yakni supplier dari tiap bahan baku PT Nyonya Meneer Semarang. Kuesioner ini menggunakan 5 skala (skala Likert), diantaranya sangat buruk, buruk, cukup, baik dan sangat baik. Sebagai contoh penilaian kinerja supplier bahan baku supplier $\mathrm{U}, \mathrm{V}$ dan W. Responden 1 memberi penilaian supplier terhadap subkriteria A1 (kemampuan memanajemen tingkat kecacatan), dimana supplier $\mathrm{U}$ dengan nilai 3 yang artinya kemampuan supplier $\mathrm{U}$ dalam memanajemen tingkat kecacatan pasokan bahan baku adalah Sedang, untuk supplier $\mathrm{V}$ dengan nilai 5 yang artinya kemampuan supplier $\mathrm{V}$ dalam memanajemen tingkat kecacatan pasokan bahan baku adalah Sangat Baik, sedangkan supplier W dengan nilai 1 yang artinya kemampuan supplier $\mathrm{W}$ dalam memanajemen tingkat kecacatan pasokan bahan baku adalah Sangat Buruk dsb. Tahapan selanjutnya adalah menghitung rata-rata untuk setiap subkriteria hasil kuesioner judgment dari tiga responden. Hasil rekapitulasi matriks keputusan terdapat pada Tabel 11 .

1. Menghitung normalisasi matriks keputusan. Hasil rekapitulasi matriks keputusan normalisasi dapat dilihat pada Tabel 12. Normalized value dari $\eta_{j}$ dapat dihitung dengan rumus:

$$
r_{i j}=\frac{x_{i j}}{\sqrt{\sum_{i=1} x_{i j}^{2}}} \mathrm{i}=1,2,3, \ldots, \mathrm{m} ; \text { dan } \mathrm{j}=1,2,3 \text {, }
$$$$
\ldots, \mathrm{n} \ldots \ldots \ldots .(9)
$$

2. Pembobotan pada matriks yang telah dinormalisasikan. Dengan bobot $w_{j}=\left(w_{1}, w_{2}, w_{3}\right.$, $\left.\ldots, w_{\mathrm{m}}\right)$, dimana $w_{j}$ adalah bobot dari kriteria ke$\mathrm{j}$ dan $\sum_{j=1} w_{j}=1$. Nilai weighted normalized $v_{j j}$ dapat dihitung dengan rumus berikut

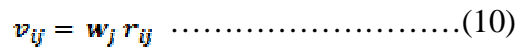

Sebagai contoh, pada Tabel 12 nilai matriks keputusan normalisasi untuk subkriteria A1 terhadap supplier A adalah 0,5212. Kemudian 0,5212 dikalikan dengan bobot subkriteria A1 pada Tabel 7 yakni sebasar 0,1007. Sehingga diperoleh nilai matriks keputusan normalisasi terbobot untuk subkriteria A1 (kemampuan memanajemen tingkat kecacatan) terhadap bahan baku jahe supplier A adalah 0,0524. Cara perhitungan yang sama dilakukan untuk seluruh subkriteria dan supplier terkait, hasil rekapitulasi matriks keputusan normalisasi terbobot dapat dilihat pada Tabel 13 .

3. Menentukan matriks solusi ideal positif dan solusi ideal negatif. Untuk setiap subkriteria, dipilih nilai terbesar dan terkecil yang sebagai solusi ideal positif dan negatif dapat dilihat pada Tabel 
14. Dapat ditentukan berdasarkan ranking bobot ternormalisasi (vij) sebagai berikut :

$A^{+}\left\{\left(\max v_{i j} \mid \mathbf{j} € \mathrm{~J}\right),\left(\min v_{i j} \mid j € J\right), i=1,2,3, ., \mathbf{m}\right\}$

$=\left\{v_{1}^{+}, v_{2}^{+}, v_{3}^{+}, \ldots . ., v_{n}^{+}\right\}$.

$A^{-}\left\{\left(\min v_{i} \mid \mathrm{j} € \mathrm{~J}\right),\left(\max v_{i} \mid j € J^{\prime}\right), i=1,2,3, . ., \mathrm{m}\right\}$

$=\left\{v_{1}, v_{2}, v_{3}, \ldots ., v_{n}^{-}\right\}$.

Dimana:

$\mathbf{J}=\{\mathrm{j}=1,2,3, \ldots, \mathrm{n}$ dan $\mathbf{J}$ merupakan himpunan kriteria manfaat (benefit criteria) $\}$.

$\mathbf{J}^{\prime}=\{\mathrm{j}=1,2,3, \ldots, \mathrm{n}$ dan $\mathrm{J}$ ' merupakan himpunan kriteria biaya (cost criteria) $\}$.

dimana $v_{i j}$ adalah elemen dari matriks keputusan yang ternormalisai terbobot,

$v_{j}^{+}(\mathrm{j}=1,2,3, \ldots, \mathrm{n})$ adalah elemen matriks solusi ideal positif,

$v_{j}^{-}(\mathrm{j}=1,2,3, \ldots, \mathrm{n})$ adalah elemen matriks solusi ideal negatif.

4. Menghitung Separation/jarak (jarak dengan solusi ideal). Separation measure ini merupakan suatu pengukuran jarak dari suatu alternatif ke solusi ideal positif maupun solusi ideal negatif. Perhitungan jarak tersebut menggunakan rumus sebagai berikut:

a. $5^{+}$adalah jarak alternatif dari solusi ideal positif didefinisikan sebagai:

$s_{i}^{+}=\sqrt{\sum_{j-1}^{n}\left(\boldsymbol{V}_{i}-v_{J}^{+}\right)^{2}}$, dengan $\mathrm{i}=1,2,3, . ., \mathrm{m}$..(13)

b. $5^{-}$adalah jarak alternatif dari solusi ideal negatif didefinisikan sebagai:

$s_{i}=\sqrt{\sum_{j=1}^{n}\left(V_{i}-V_{\bar{l}}\right)^{2}}$, dengan $\mathrm{i}=1,2,3, \mathrm{~m} \ldots(14)$

Perhitungan jarak terhadap solusi ideal positif dan solusi ideal negatif dapat dilihat pada Tabel 15 .

5. Menghitung kedekatan relatif terhadap solusi ideal. Kedekatan relatif dari setiap alternatif $\left(c_{\mathbb{i}}^{+}\right)$ dapat dihitung dengan menggunakan persamaan berikut:

$c_{i}^{+}=\frac{s_{i}^{-}}{\left(s_{i}^{-}+s_{i}^{+}\right)}, 0 \leq c_{i}^{+} \leq 1$

Berdasarkan hasil perhitungan, diperoleh nilai kedekatan tiap supplier (Tabel 16).

Tabel 8. Hasil Nilai Kepentingan Rata-Rata Tiap Kriteria

\begin{tabular}{|c|c|c|c|c|c|c|}
\hline Kriteria & & & & \multicolumn{3}{|c|}{ Average Score $\left(\overline{\bar{\theta}}_{m}\right)$} \\
\hline Supply risk & Res 1 & Res 2 & Res 3 & $\mathrm{a}$ & $\mathrm{b}$ & $\mathrm{c}$ \\
\hline Kompetisi & $\{5,6,7\}$ & $\{6,7,8\}$ & $\{7,8,9\}$ & 6,000 & 7,000 & 8,000 \\
\hline Lead time & $\{6,7,8\}$ & $\{5,6,7\}$ & $\{6,7,8\}$ & 5,667 & 6,667 & 7,667 \\
\hline Ketersediaan item pengganti & $\{7,8,9\}$ & $\{7,8,9\}$ & $\{6,7,8\}$ & 6,667 & 7,667 & 8,667 \\
\hline $\begin{array}{l}\text { Jumlah supplier yang } \\
\text { digunakan }\end{array}$ & $\{8,9,10\}$ & $\{7,8,9\}$ & $\{8,9,10\}$ & 7,667 & 8,667 & 9,667 \\
\hline Resiko penyimpanan & $\{7,8,9\}$ & $\{8,9,10\}$ & $\{8,9,10\}$ & 7,667 & 8,667 & 9,667 \\
\hline Kelangkaan item & $\{5,6,7\}$ & $\{3,4,5\}$ & $\{4,5,6\}$ & 4,000 & 5,000 & 6,000 \\
\hline Jumlah supplier yang potensial & $\{3,4,5\}$ & $\{4,5,6\}$ & $\{2,3,4\}$ & 3,000 & 4,000 & 5,000 \\
\hline Profit Impact & Res 1 & Res 2 & Res 3 & $\mathrm{~A}$ & $\mathrm{~B}$ & $\mathrm{C}$ \\
\hline Volume jumlah pembelian & $\{6,7,8\}$ & $\{5,6,7\}$ & $\{5,6,7\}$ & 5,333 & 6,333 & 7,333 \\
\hline Harga item & $\{7,8,9\}$ & $\{8,9,10\}$ & $\{7,8,9\}$ & 7,333 & 8,333 & 9,333 \\
\hline Kualitas item & $\{6,7,8\}$ & $\{7,8,9\}$ & $\{7,8,9\}$ & 6,667 & 7,667 & 8,667 \\
\hline
\end{tabular}

Tabel 9. Normalisasi Bobot Untuk Tiap Kriteria

\begin{tabular}{lc}
\hline Supply risk & NWm \\
\hline Kompetisi & 0,147 \\
Lead time & 0,140 \\
Ketersediaan item pengganti & 0,161 \\
Jumlah supplier yang digunakan & 0,182 \\
Resiko penyimpanan & 0,182 \\
Kelangkaan item & 0,104 \\
Jumlah supplier yang potensial & 0,083 \\
Total & 1,000 \\
\hline Profit Impact & NWm \\
\hline Volume jumlah pembelian & 0,283 \\
Harga item & 0,374 \\
Kualitas item & 0,343 \\
Total & 1,000 \\
\hline
\end{tabular}


Tabel 10. Performance Score dan Average Performance Score

\begin{tabular}{lccccc}
\hline Supply risk & Jahe & Temulawak & Kencur & Sambiloto & Pegagan \\
\hline Ketersediaan item pengganti & 0,913 & 0,859 & 0,913 & 0,859 & 1,021 \\
Lead time & 0,885 & 0,839 & 0,792 & 0,746 & 0,606 \\
Resiko penyimpanan & 1,399 & 1,338 & 1,217 & 1,156 & 1,156 \\
Jumlah supplier yang & 1,217 & 1,095 & 1,095 & 0,973 & 1,034 \\
digunakan & 0,735 & 0,735 & 0,735 & 0,686 & 0,784 \\
Kompetisi & 0,625 & 0,556 & 0,591 & 0,556 & 0,556 \\
Kelangkaan item & 0,442 & 0,442 & 0,442 & 0,387 & 0,359 \\
Jumlah supplier yang & 6,217 & 5,864 & 5,784 & 5,363 & 5,515 \\
potensial & 2,487 & 2,346 & 2,314 & 2,145 & 2,206 \\
Weighted average & Jahe & Temulawak & Kencur & Sambiloto & Pegagan \\
Global average & 2.169 & 1.981 & 1.886 & 1.320 & 1.320 \\
\hline Profit Impact & 1.868 & 2.242 & 2.117 & 2.615 & 2.865 \\
\hline Volume jumlah pembelian & 2.633 & 2.289 & 2.289 & 1.717 & 1.603 \\
Harga item & 6.670 & 6.512 & 6.293 & 5.653 & 5.788 \\
Kualitas item & 4.002 & 3.907 & 3.776 & 3.392 & 3.473 \\
\hline Weighted average & & & & & \\
Global average & & & & \\
\hline
\end{tabular}

Tabel 11. Rekapitulasi Matriks Keputusan

\begin{tabular}{|c|c|c|c|c|c|c|c|c|c|c|c|c|c|c|c|c|}
\hline \multirow{2}{*}{$\begin{array}{c}\text { Sub } \\
\text { kriteria }\end{array}$} & \multicolumn{6}{|c|}{ Supplier Jahe } & \multicolumn{5}{|c|}{ Supplier Temulawak } & \multicolumn{5}{|c|}{ Supplier Kencur } \\
\hline & A & B & $\mathrm{C}$ & $\mathrm{D}$ & $\mathrm{E}$ & $\mathrm{F}$ & $\mathrm{G}$ & $\mathrm{H}$ & $\mathrm{I}$ & $\mathrm{J}$ & $\mathrm{K}$ & $\mathrm{L}$ & $\mathrm{M}$ & $\mathrm{N}$ & $\mathrm{O}$ & $\mathrm{P}$ \\
\hline A1 & 4 & 4,667 & 3,333 & 1,667 & 1,333 & 2,333 & 3 & 4 & 4,667 & 1,667 & 2,667 & 1 & 2 & 3,333 & 3 & 4,667 \\
\hline A2 & 3,333 & 3,667 & 3,333 & 2,333 & 2 & 2,667 & 4 & 3,333 & 3,333 & 3 & 2 & 4 & 3 & 3 & 3,667 & 3,667 \\
\hline A3 & 3 & 4 & 4,333 & 3 & 2,667 & 4 & 3,333 & 3,667 & 4 & 4 & 3 & 4 & 4 & 3,667 & 3 & 4 \\
\hline B1 & 3 & 2,667 & 4,333 & 5 & 4 & 3,333 & 2 & 4,333 & 1 & 5 & 4,333 & 3 & 4 & 5 & 1 & 3 \\
\hline B2 & 4,667 & 4 & 3 & 4 & 3,333 & 2 & 3,667 & 2,667 & 4 & 3 & 2 & 2,667 & 3 & 3,333 & 4 & 3,667 \\
\hline B3 & 3,333 & 4 & 3 & 2 & 4 & 3,333 & 3,667 & 3 & 4 & 3,667 & 3 & 4 & 2,667 & 3 & 3,333 & 3,667 \\
\hline $\mathrm{C} 1$ & 2,667 & 4 & 3 & 3,333 & 4 & 4 & 4 & 3,333 & 3,333 & 3 & 4 & 3 & 3 & 2,667 & 3,333 & 3,667 \\
\hline C2 & 3,667 & 4 & 1,333 & 3 & 2 & 3 & 2,333 & 4 & 3 & 1 & 1,667 & 3 & 1,667 & 4,333 & 2 & 4 \\
\hline D1 & 2,333 & 3,333 & 4 & 3 & 2 & 3 & 4 & 3,667 & 3,333 & 3 & 3,667 & 4 & 3,333 & 3,333 & 3 & 3 \\
\hline D2 & 4 & 3 & 3,333 & 3 & 2,667 & 4 & 3,333 & 3 & 3,333 & 4 & 2,667 & 2,333 & 3,333 & 3 & 3 & 3,667 \\
\hline D3 & 3 & 4 & 4 & 3 & 2,333 & 3,333 & 4 & 3,333 & 3,333 & 3 & 3 & 3 & 3,333 & 3,667 & 3,333 & 3 \\
\hline E1 & 4 & 3 & 4 & 3 & 2,667 & 3 & 3 & 4 & 3,667 & 3,667 & 3 & 2667 & 3 & 3,333 & 3 & 3,667 \\
\hline E2 & 2,333 & 3,333 & 3 & 3,667 & 2,667 & 4 & 3,667 & 3,333 & 4 & 3 & 3 & 3,333 & 2 & 3 & 3,333 & 3 \\
\hline
\end{tabular}

Tabel 12. Normalisasi Matriks Keputusan

\begin{tabular}{|c|c|c|c|c|c|c|c|c|c|c|c|c|c|c|c|c|}
\hline \multirow{2}{*}{$\begin{array}{c}\text { Sub } \\
\text { kriteria }\end{array}$} & \multicolumn{6}{|c|}{ Supplier Jahe } & \multicolumn{5}{|c|}{ Supplier Temulawak } & \multicolumn{5}{|c|}{ Supplier Kencur } \\
\hline & A & B & $\mathrm{C}$ & $\mathrm{D}$ & $\mathrm{E}$ & $\mathrm{F}$ & G & $\mathrm{H}$ & I & $\mathrm{J}$ & $\mathrm{K}$ & $\mathrm{L}$ & $\mathrm{M}$ & $\mathrm{N}$ & $\mathrm{O}$ & $\mathrm{P}$ \\
\hline A1 & 0,521 & 0,608 & 0,434 & 0,217 & 0,174 & 0,304 & 0,399 & 0,531 & 0,620 & 0,221 & 0,354 & 0,146 & 0,292 & 0,487 & 0,438 & 0,682 \\
\hline A2 & 0,461 & 0,507 & 0,461 & 0,323 & 0,277 & 0,369 & 0,559 & 0,466 & 0,466 & 0,419 & 0,279 & 0,513 & 0,385 & 0,385 & 0,470 & 0,470 \\
\hline A3 & 0,344 & 0,459 & 0,497 & 0,344 & 0,306 & 0,459 & 0,412 & 0,453 & 0,494 & 0,494 & 0,371 & 0,477 & 0,477 & 0,437 & 0,357 & 0,477 \\
\hline B1 & 0,322 & 0,286 & 0,465 & 0,536 & 0,429 & 0,357 & 0,243 & 0,527 & 0,122 & 0,608 & 0,527 & 0,387 & 0,516 & 0,646 & 0,129 & 0,387 \\
\hline B2 & 0,529 & 0,453 & 0,340 & 0,453 & 0,378 & 0,227 & 0,521 & 0,379 & 0,568 & 0,426 & 0,284 & 0,354 & 0,399 & 0,443 & 0,531 & 0,487 \\
\hline B3 & 0,407 & 0,488 & 0,367 & 0,244 & 0,488 & 0,407 & 0,470 & 0,385 & 0,513 & 0,470 & 0,385 & 0,531 & 0,354 & 0,399 & 0,443 & 0,487 \\
\hline $\mathrm{C} 1$ & 0,308 & 0,461 & 0,346 & 0,384 & 0,461 & 0,461 & 0,503 & 0,419 & 0,419 & 0,377 & 0,503 & 0,426 & 0,426 & 0,378 & 0,473 & 0,520 \\
\hline $\mathrm{C} 2$ & 0,503 & 0,548 & 0,183 & 0,411 & 0,274 & 0,411 & 0,399 & 0,684 & 0,513 & 0,171 & 0,285 & 0,422 & 0,234 & 0,609 & 0,281 & 0,563 \\
\hline D1 & 0,316 & 0,451 & 0,542 & 0,406 & 0,271 & 0,406 & 0,504 & 0,462 & 0,420 & 0,378 & 0,462 & 0,534 & 0,445 & 0,445 & 0,400 & 0,400 \\
\hline D2 & 0,484 & 0,363 & 0,404 & 0,363 & 0,323 & 0,484 & 0,452 & 0,407 & 0,452 & 0,543 & 0,362 & 0,337 & 0,481 & 0,433 & 0,433 & 0,529 \\
\hline D3 & 0,368 & 0,490 & 0,490 & 0,368 & 0,286 & 0,409 & 0,534 & 0,445 & 0,444 & 0,400 & 0,400 & 0,410 & 0,455 & 0,501 & 0,455 & 0,410 \\
\hline E1 & 0,492 & 0,369 & 0,492 & 0,369 & 0,328 & 0,369 & 0,385 & 0,513 & 0,470 & 0,470 & 0,385 & 0,378 & 0,426 & 0,473 & 0,426 & 0,520 \\
\hline E2 & 0,296 & 0,423 & 0,381 & 0,465 & 0,338 & 0,508 & 0,479 & 0,436 & 0,523 & 0,392 & 0,392 & 0,501 & 0,301 & 0,451 & 0,501 & 0,451 \\
\hline
\end{tabular}


Tabel 13. Matriks Keputusan Weighted Normalized

\begin{tabular}{ccccccccccccccccccc}
\hline Sub & \multicolumn{1}{c}{ Supplier Jahe } & \multicolumn{1}{c}{ Supplier Temulawak } & \multicolumn{4}{c}{ Supplier Kencur } \\
kriteria & $\mathrm{A}$ & $\mathrm{B}$ & $\mathrm{C}$ & $\mathrm{D}$ & $\mathrm{E}$ & $\mathrm{F}$ & $\mathrm{G}$ & $\mathrm{H}$ & $\mathrm{I}$ & $\mathrm{J}$ & $\mathrm{K}$ & $\mathrm{L}$ & $\mathrm{M}$ & $\mathrm{N}$ & $\mathrm{O}$ & $\mathrm{P}$ \\
A1 & 0,052 & 0,061 & 0,044 & 0,022 & 0,018 & 0,031 & 0,040 & 0,053 & 0,062 & 0,022 & 0,036 & 0,015 & 0,029 & 0,049 & 0,044 & 0,069 \\
A2 & 0,016 & 0,018 & 0,016 & 0,012 & 0,010 & 0,013 & 0,020 & 0,017 & 0,017 & 0,015 & 0,010 & 0,018 & 0,014 & 0,014 & 0,017 & 0,017 \\
A3 & 0,029 & 0,039 & 0,042 & 0,029 & 0,026 & 0,039 & 0,035 & 0,038 & 0,042 & 0,042 & 0,031 & 0,040 & 0,040 & 0,037 & 0,030 & 0,040 \\
B1 & 0,088 & 0,078 & 0,127 & 0,147 & 0,117 & 0,098 & 0,067 & 0,144 & 0,033 & 0,166 & 0,144 & 0,106 & 0,141 & 0,177 & 0,035 & 0,106 \\
B2 & 0,037 & 0,032 & 0,024 & 0,032 & 0,026 & 0,016 & 0,037 & 0,027 & 0,040 & 0,030 & 0,020 & 0,025 & 0,028 & 0,031 & 0,037 & 0,034 \\
B3 & 0,040 & 0,048 & 0,036 & 0,024 & 0,048 & 0,040 & 0,046 & 0,038 & 0,050 & 0,046 & 0,038 & 0,052 & 0,035 & 0,039 & 0,043 & 0,048 \\
C1 & 0,017 & 0,026 & 0,020 & 0,022 & 0,026 & 0,026 & 0,029 & 0,024 & 0,024 & 0,021 & 0,029 & 0,024 & 0,024 & 0,021 & 0,027 & 0,030 \\
C2 & 0,027 & 0,030 & 0,010 & 0,022 & 0,015 & 0,022 & 0,022 & 0,037 & 0,028 & 0,009 & 0,016 & 0,023 & 0,013 & 0,033 & 0,015 & 0,031 \\
D1 & 0,004 & 0,006 & 0,008 & 0,006 & 0,004 & 0,006 & 0,007 & 0,007 & 0,006 & 0,005 & 0,007 & 0,008 & 0,006 & 0,006 & 0,006 & 0,006 \\
D2 & 0,016 & 0,012 & 0,014 & 0,012 & 0,011 & 0,016 & 0,015 & 0,014 & 0,015 & 0,018 & 0,012 & 0,011 & 0,016 & 0,015 & 0,015 & 0,018 \\
D3 & 0,043 & 0,058 & 0,058 & 0,043 & 0,034 & 0,048 & 0,063 & 0,052 & 0,052 & 0,047 & 0,047 & 0,048 & 0,054 & 0,059 & 0,054 & 0,048 \\
E1 & 0,014 & 0,011 & 0,014 & 0,011 & 0,010 & 0,011 & 0,011 & 0,015 & 0,014 & 0,014 & 0,011 & 0,011 & 0,012 & 0,014 & 0,012 & 0,015 \\
E2 & 0,010 & 0,014 & 0,013 & 0,015 & 0,011 & 0,017 & 0,016 & 0,014 & 0,017 & 0,013 & 0,013 & 0,017 & 0,010 & 0,015 & 0,017 & 0,015 \\
\hline
\end{tabular}

Tabel 14. Rekapitulasi Solusi Ideal Positif Dan Solusi Ideal Negatif

\begin{tabular}{ccccccc}
\hline \multirow{2}{*}{ Subkriteria } & \multicolumn{2}{c}{ Jahe } & \multicolumn{2}{c}{ Temulawak } & \multicolumn{2}{c}{ Kencur } \\
\cline { 2 - 7 } & Solusi & Solusi & Solusi & Solusi & Solusi & Solusi \\
& Positif & Negatif & Positif & Negatif & Positif & Negatif \\
\hline A1 & 0,0612 & 0,0175 & 0,0623 & 0,0223 & 0,0685 & 0,0147 \\
A2 & 0,018 & 0,0098 & 0,0198 & 0,0099 & 0,0182 & 0,0136 \\
A3 & 0,042 & 0,0259 & 0,0417 & 0,0313 & 0,0403 & 0,0302 \\
B1 & 0,0782 & 0,1467 & 0,0333 & 0,1664 & 0,0353 & 0,1766 \\
B2 & 0,0159 & 0,037 & 0,0199 & 0,0398 & 0,0310 & 0,0372 \\
B3 & 0,0238 & 0,0476 & 0,0375 & 0,0501 & 0,0346 & 0,0519 \\
C1 & 0,0261 & 0,0174 & 0,0285 & 0,0214 & 0,0295 & 0,0214 \\
C2 & 0,0298 & 0,0099 & 0,0372 & 0,0093 & 0,0331 & 0,0127 \\
D1 & 0,0076 & 0,0038 & 0,0071 & 0,0053 & 0,0075 & 0,0056 \\
D2 & 0,0163 & 0,0108 & 0,0182 & 0,0121 & 0,0178 & 0,0113 \\
D3 & 0,0577 & 0,0336 & 0,0627 & 0,047 & 0,0589 & 0,0482 \\
E1 & 0,0142 & 0,0095 & 0,0136 & 0,0111 & 0,0150 & 0,0137 \\
E2 & 0,0168 & 0,0098 & 0,0173 & 0,013 & 0,0166 & 0,0100 \\
\hline
\end{tabular}

Tabel 15. Hasil Perhitungan Jarak Antara Nilai Terbobot Setiap Supplier Terhadap Solusi Ideal

\begin{tabular}{ccccccccc}
\hline Supplier & $\begin{array}{c}\text { Solusi } \\
\text { Ideal } \\
\text { Positif }\end{array}$ & $\begin{array}{c}\text { Solusi } \\
\text { Ideal } \\
\text { Negatif }\end{array}$ & Supplier & $\begin{array}{c}\text { Solusi } \\
\text { Ideal } \\
\text { Positif }\end{array}$ & $\begin{array}{c}\text { Solusi } \\
\text { Ideal } \\
\text { Negatif }\end{array}$ & Supplier & $\begin{array}{c}\text { Solusi } \\
\text { Ideal } \\
\text { Positif }\end{array}$ & $\begin{array}{c}\text { Solusi } \\
\text { Ideal } \\
\text { Negatif }\end{array}$ \\
\hline A & 0,0373 & 0,0723 & G & 0,0475 & 0,1044 & L & 0,0924 & 0,0737 \\
B & 0,029 & 0,089 & H & 0,1123 & 0,0521 & M & 0,1154 & 0,0449 \\
C & 0,058 & 0,0482 & I & 0,0281 & 0,1411 & N & 0,1431 & 0,0446 \\
D & 0,0837 & 0,0305 & J & 0,1436 & 0,0171 & O & 0,0345 & 0,145 \\
E & 0,0731 & 0,0328 & K & 0,1184 & 0,0362 & P & 0,0728 & 0,0921 \\
F & 0,042 & 0,0614 & & & & & & \\
\hline
\end{tabular}

Tabel 16. Urutan Prioritas Supplier

\begin{tabular}{cccc}
\hline \multirow{2}{*}{ Rangking } & \multicolumn{3}{c}{ Supplier } \\
\cline { 2 - 4 } & Jahe & Temulawak & Kencur \\
\hline 1 & $\mathrm{~B}(0,7514)$ & $\mathrm{I}(0,8337)$ & $\mathrm{O}(0,8077)$ \\
2 & $\mathrm{~A}(0,6597)$ & $\mathrm{G}(0,6874)$ & $\mathrm{P}(0,5585)$ \\
3 & $\mathrm{~F}(0,5936)$ & $\mathrm{H}(0,31697)$ & $\mathrm{L}(0,4438)$ \\
4 & $\mathrm{C}(0,4539)$ & $\mathrm{K}(0,2344)$ & $\mathrm{M}(0,2799)$ \\
5 & $\mathrm{E}(0,3097)$ & $\mathrm{J}(0,1065)$ & $\mathrm{N}(0,2377)$ \\
6 & $\mathrm{D}(0,2671)$ & & \\
\hline
\end{tabular}




\section{Pembahasan}

Hasil identifikasi tingkat kekritisan item bahan baku menggunakan model Kraljic Portfolio Matrix (KPM). Dimana terdapat 3 bahan baku yang berada pada kuadran critical diantaranya jahe, temulawak dan kencur, bahan baku sambiloto berada pada kuadran leverage sedangkan pegagan berada pada kuadran routine. Sedangkan hasil pembobotan subkriteria dalam pemilihan supplier menggunakan metode ANP, didapat nilai bobot kepentingan paling tinggi pada subkriteria penentuan prioritas supplier di PT Nyonya Meneer Semarang adalah harga penawaran $(0,2736)$, responsiveness $(0,117595)$, kemampuan memanajemen tingkat kecacatan $(0,10056)$, biaya transportasi $(0,09764)$, kadar air/tingkat kekeringan bahan baku (0,08448), potongan harga $(0,0700)$, ketepatan kuantitas pesanan $(0,05666)$, ketepatan waktu pengiriman $(0,05435)$, tingkat pengembalian $(0,03547)$, comunication system $(0,03357)$, fleksibel terhadap perubahan waktu pengiriman $(0,03312)$, fleksibel terhadap perubahan jumlah pesanan $(0,02889)$, dan bobot terendah adalah waranties and claim policies $(0,0140)$. Hasil perhitungan dengan metode TOPSIS, urutan prioritas untuk supplier jahe antara lain supplier B, A, F, C, E dan D. Untuk supplier temulawak antara lain supplier I, G, H, K, dan J. Sedangkan untuk supplier kencur antara lain supplier $\mathrm{O}, \mathrm{P}, \mathrm{L}, \mathrm{M}$, dan $\mathrm{N}$ seperti yang terlihat pada Tabel 16 .

Berdasarkan hasil penelitian ini dapat ditarik beberapa rekomendasi untuk perusahaan, yakni dalam upaya perusahaan untuk meningkatkan keuntungan dan resiko yang diakibatkan dalam proses pengadaan bahan baku adalah dengan menentukan strategi pengadaan yang tepat sesuai dengan tingkat kekritisan dari bahan baku. Dimana penentuan prioritas supplier untuk routine items dengan mempertimbangkan harga terendah dari supplier, sedangkan untuk critical items mempertimbangkan 5 kriteria dan 13 subkriteria karena critical items merupakan item-item dengan resiko yang tinggi pada proses pengadaan merupakan item-item dengan resiko yang tinggi pada proses pengadaannya sehingga membutuhkan pertimbangkan beberapa kriteria, dimana kriteria tersebut disesuaikan dengan strategi perusahaan.

Hubungan antara perusahaan dengan supplier yang tepat untuk routine items adalah melakukan pembelian dan pemesanan barang/jasa secara langsung dimana strategi pengadaan secara langsung bertujuan untuk mengurangi besarnya biaya administrasi. Sedangkan untuk critical items adalah dengan menjalin hubungan baik dengan supplier agar supplier tidak terlalu mudah untuk menaikkan harga bahan baku dan tidak menurunkan kualitas dari bahan baku. Dan tipe kontrak yang sesuai untuk routine items adalah call-off contract atau fixed contract, sedangkan untuk critical items adalah partnership contract.

\section{Kesimpulan}

Hasil identifikasi tingkat kekritisan item bahan baku menggunakan model Kraljic Portfolio Matrix (KPM). Dimana terdapat 3 bahan baku yang berada pada kuadran critical diantaranya jahe, temulawak dan kencur, bahan baku sambiloto berada pada kuadran leverage sedangkan pegagan berada pada kuadran routine.

Hasil pembobotan subkriteria dalam pemilihan supplier menggunakan metode ANP, didapat nilai bobot kepentingan paling tinggi pada subkriteria penentuan prioritas supplier di PT Nyonya Meneer Semarang adalah harga penawaran $(0,2736)$, responsiveness (0,117595), kemampuan memanajemen tingkat kecacatan $(0,10056)$, biaya transportasi $(0,09764)$, kadar air/tingkat kekeringan bahan baku $(0,08448)$, potongan harga $(0,0700)$, ketepatan kuantitas pesanan $(0,05666)$, ketepatan waktu pengiriman $(0,05435)$, tingkat pengembalian $(0,03547)$, comunication system $(0,03357)$, fleksibel terhadap perubahan waktu pengiriman $(0,03312)$, fleksibel terhadap perubahan jumlah pesanan $(0,02889)$, dan bobot terendah adalah waranties and claim policies $(0,0140)$.

Urutan prioritas berdasarkan metode TOPSIS untuk supplier jahe antara lain supplier B, A, F, C, E dan D. Untuk supplier temulawak antara lain supplier I, G, H, K, dan J. Sedangkan untuk supplier kencur antara lain supplier $\mathrm{O}, \mathrm{P}, \mathrm{L}, \mathrm{M}$, dan $\mathrm{N}$.

\section{Daftar Pustaka}

Deng, Hepu, (1999). "Multicriteria analysis with fuzzy pairwise comparison". International Journal of Approximate Reasoning 21 (3), 215231.

Gelderman, C.J., Caniels, Marjolein C.J, (2005). "Purchasing strategies in the Kraljic matrix-A power and dependence perspective". Journal of Purchasing \& Supply Management 11 (2005) 141-155.

Kurniawati, Dewi., Yuliando H., dan Widodo K.H., (2013) "Kriteria Pemilihan Pemasok Menggunakan Analytical Network Process" Jurnal Teknik Industri, Vol. 15, No. 1, 25- 32.

Knight, Louise., Tu, Yi-Hsi dan Preston, Jude. (2014). "Integrating skills profiling and purchasing portfolio management: An opportunity for building purchasing capability”. International Journal Production Economics 147 271-283.

Padhi, S.S., Wagner, S.M dan Aggarwal, Vijay, (2012). "Positioning of commodities using the Kraljic Portfolio Matrix". Journal of Purchasing \& Supply Management 18, 1-8

Prostean, Gabriela., Badea Andra., Vasar Cristian dan Octavian Prostean (2014), "Risk Variables In Wind Power Supply Chain", Procedia - Social and Behavioral Sciences 124 (2014 ) 124 - 132. 
Pujawan, I Nyoman. (2005). "Supply Chain Management”. Surabaya: Guna Widya.

Saaty, T.L. (1998), "The Analytic Network Process", University of Pittsburgh, USA

Shahroudi. K dan Rouydel. H. (2012) "Using a multicriteria decision making approach (ANPTOPSIS) to evaluate suppliers in Iran's auto industry". International Journal of Applied Operational Research. Vol. 2, No. 2, pp. 37-48.

Suliantoro, Hery., Nugroho, Susatyo dan Juanita, Fany, (2013). "Penerapan Model Kraljic's Matrix Purchasing Portfolio pada Strategi Pembelian Bahan Baku (Studi Kasus PT Nyonya Meneer Semarang)". Prosiding Seminar Nasional Industrial Engineering National Conference (IENACO) - 2014.
Singh, Rajesh and Sharma, S.K., (2011) "TitleSupplier Selection Fuzzy-AHP approach", International Juornal of Engineering Science and Technology, Vol. 3 No. 10.

Wardah. Siti., (2013) "Model Pemilihan Pemasok Bahan Baku Kelapa Parut Kering Dengan Metode AHP (Studi Kasus PT. Kokonako Indonesia)" Jurnal Optimasi Sistem Industri, Vol. 12 No. 2 : 352-357.

Wulandari. Fera .T., Hartono.F.B., (2014) "Penentuan Produk Kerajinan Unggulan Dengan Menggunakan MADM-TOPSIS" Jurnal Magistra No. 87 Th. XXVI Fakultas Ilmu Komputer, UNWIDHA Klaten-unpublish. 